\title{
A FAFLP system for the improved identification of plant-pathogenic and plant-associated species of the genus Pantoea
}

\section{Carrie Brady ${ }^{\mathrm{a}}$, Stephanus Venter ${ }^{\mathrm{a}}$, Ilse Cleenwerck ${ }^{\mathrm{b}}$, Marc Vancanneyt ${ }^{\mathrm{b}}$, Jean Swings ${ }^{b}$ and Teresa Coutinho ${ }^{a}$}

${ }^{a}$ Department of Microbiology and Plant Pathology, Forestry and Agricultural Biotechnology Institute (FABI), University of Pretoria, Pretoria 0002, South Africa

${ }^{\mathrm{b}} \mathrm{BCCM} / \mathrm{LMG}$ Bacteria Collection, Ghent University, K.L. Ledeganckstraat 35, B-9000 Ghent, Belgium

\section{Abstract}

The majority of Pantoea species are either plant-pathogenic or plant-associated and cause a wide variety of symptoms on a range of hosts. Identification of Pantoea species is difficult due to minor differences in phenotypic characteristics between them and related Enterobacteriaceae. Fluorescent amplified fragment length polymorphism (FAFLP) analysis was investigated for use as a rapid, molecular-based identification technique to the species level of the genus Pantoea. Following analysis of the band patterns generated by FAFLP, seven distinct clusters were observed, one for each validly published species of the genus. FAFLP has proven to be a rapid, reproducible identification technique for all species of the genus Pantoea.

\section{Article Outline}

Introduction

Bacterial strains 
FAFLP analysis

Gel analysis

Reproducibility

FAFLP analysis of Pantoea species

Acknowledgements

Appendix A. Supplemental material

References

\section{Introduction}

Identification of plant-pathogenic Pantoea species is difficult, due to the high degree of phenotypic similarity between species of this genus and related Enterobacteriaceae [20]. Pantoea species are typically characterised based on colony morphology, physiological and biochemical tests, and in some cases, fatty acid analysis or quinone composition. This approach has proven to be unreliable though, as identification based solely on phenotypic characteristics has led to the misidentification of many strains belonging to the now obsolete "Erwinia herbicola-Enterobacter agglomerans" complex.

The genus Pantoea currently includes seven species, the majority of which are either plant-pathogenic or plant-associated. The most notorious of the plant-pathogenic species is undoubtedly Pantoea stewartii subsp. stewartii, the causal agent of Stewart's vascular wilt of sweet corn and maize [18], whereas P. stewartii subsp. indologenes is associated with sudangrass [3] and is thought to cause leaf spot on foxtail millet and pearl millet and rot of pineapple. Pantoea agglomerans is best known for causing crown and root gall of Gypsophila paniculata [6] and Pantoea ananatis causes a range of diseases on a wide variety of agricultural crops, the most recent including rice [8], Eucalyptus [9], maize [14] and sudangrass [3]. Pantoea citrea is associated with citrus fruit and causes pink disease of pineapple [11] and [15]. Although Pantoea dispersa, Pantoea punctata and Pantoea terrea have been isolated from the environment, they have not been found to be associated with diseases of plants. By utilising typical identification techniques such as Gram staining, oxidation/fermentation tests and the API 20E system (bioMérieux, Marcy 
l'Etoile, France), strains may be correctly identified as belonging to the genus Pantoea but often cannot be accurately assigned to a species [10]. There are a few PCR-based techniques for the identification of $P$. stewartii subsp. stewartii [7] and [23] and $P$. ananatis [22], but these PCR assays cannot be applied to all seven species of the genus Pantoea. Sequencing of the 16S rRNA gene is also routinely used in the identification of bacterial species and is considered to be a standard element for the description of bacterial taxa. However, 16S rRNA sequences are too highly conserved to differentiate reliably between closely related species [17], as is the case for Pantoea (unpublished results).

Alternatively, amplified fragment length polymorphism (AFLP) analysis can be used for identification and typing purposes as it can discriminate to, or below, the species level [16]. Also, AFLP has been used extensively in the identification and classification of bacteria belonging to the Enterobacteriaceae, including Escherichia and Erwinia [1] and [2]. Therefore, the purpose of this study was to investigate the use of fluorescent AFLP (FAFLP) analysis [21] for identification, to the species level, of strains belonging to the genus Pantoea.

\section{Bacterial strains}

Thirty-five Pantoea strains (Supplementary Table S1), including the type strains of all seven species, and 10 type strains of plant-pathogenic species belonging to Erwinia, Pectobacterium and Brenneria were received from the BCCM/LMG Bacteria Collection (http://bccm.belspo.be). Fourteen additional Pantoea strains were obtained from culture collections and institutions in Australia, Japan, Sweden, Israel and the USA and they were deposited in the BCC Collection at the Forestry and Agricultural Biotechnology Institute (FABI), University of Pretoria.

\section{FAFLP analysis}

Genomic DNA was extracted using a DNeasy ${ }^{\mathrm{TM}}$ tissue kit (Qiagen, Hilden, Germany) and stored at $-20^{\circ} \mathrm{C}$. The FAFLP method of Vos et al. [21] was followed as described, but with some modifications. Between 100 and 150 ng of DNA from each of the strains was digested with $12 \mathrm{U}$ EcoRI (Roche, Basel, Switzerland) and $8 \mathrm{U}$ MseI (Roche) in 5× 
restriction/ligation buffer (50 mM Tris HAc, $50 \mathrm{mM} \mathrm{MgAc}, 250 \mathrm{mM} \mathrm{KAc}$ and $25 \mathrm{mM}$ DTT). The digestion reaction was incubated at $37^{\circ} \mathrm{C}$ for $2 \mathrm{~h}$ and then heated at $70{ }^{\circ} \mathrm{C}$ for $15 \mathrm{~min}$. Double-stranded adaptors, $5 \mathrm{pmol}$ EcoRI and $50 \mathrm{pmol}$ MseI, were added to the $15 \mu$ digestion mixture, together with $5 \times$ restriction/ligation buffer, $0.3 \mathrm{mM} \mathrm{ATP}$ and 1 U T4 DNA ligase (Roche). The ligation reaction was incubated at room temperature for $2 \mathrm{~h}$ and then diluted 1:10 with nuclease-free water. Pre-amplification reactions were performed and contained $1 \times$ reaction buffer, $1.5 \mathrm{mM} \mathrm{MgCl}_{2}, 250 \mu \mathrm{M}$ dNTPs, 100 pmol each of Eco-00 (GACTGCGTACCAATTC) and Mse-00 primer (GATGAGTCCTGACTAA), 1 U Taq DNA polymerase (JMR Holdings, Kent, UK) and $2 \mu \mathrm{l}$ diluted ligation reaction product. The amplification conditions included denaturation at $94{ }^{\circ} \mathrm{C}$ for $3 \mathrm{~min}, 20$ cycles of denaturation at $94{ }^{\circ} \mathrm{C}$ for $30 \mathrm{~s}$, annealing at $56{ }^{\circ} \mathrm{C}$ for $1 \mathrm{~min}$ and elongation at $72{ }^{\circ} \mathrm{C}$ for $1 \mathrm{~min}$, and extension at $72{ }^{\circ} \mathrm{C}$ for a further $5 \mathrm{~min}$. Following pre-amplification, each reaction was diluted 1:50 with nuclease-free water. The selective amplification reactions, in a total volume of $20 \mu \mathrm{l}$, contained $1 \times$ reaction buffer, $1.5 \mathrm{mM} \mathrm{MgCl} 2,250 \mu \mathrm{M}$ dNTPs, 0.5 pmol fluorescently labelled Eco-C primer (GACTGCGTACCAATTCC), 2.4 pmol Mse-GC primer (GATGAGTCCTGAGTAAGC), 1 U Taq DNA polymerase (Southern Cross Biotechnologies) and $5 \mu$ diluted pre-amplification reaction product. The selective PCR conditions included denaturation at $94{ }^{\circ} \mathrm{C}$ for $5 \mathrm{~min}$, nine cycles of denaturation at $94{ }^{\circ} \mathrm{C}$ for $30 \mathrm{~s}$, annealing at $65^{\circ} \mathrm{C}$ for $30 \mathrm{~s}$ and elongation at $72^{\circ} \mathrm{C}$ for $1 \mathrm{~min}$, where the annealing temperature decreases by $1{ }^{\circ} \mathrm{C} /$ cycle until $56{ }^{\circ} \mathrm{C}$ is reached. This was followed by 23 cycles of denaturation at $94{ }^{\circ} \mathrm{C}$ for $30 \mathrm{~s}$, annealing at $56^{\circ} \mathrm{C}$ for $30 \mathrm{~s}$ and elongation at $72{ }^{\circ} \mathrm{C}$ for $1 \mathrm{~min}$, and a further $5 \mathrm{~min}$ of extension at $72{ }^{\circ} \mathrm{C}$. The separation of FAFLP fragments was performed using a LI-COR IR2 automated sequencer (LI-COR Biosciences, Lincoln, Nebraska, USA) following the protocol of Myburg et al. [13].

\section{Gel analysis}

The band patterns from the gels were analysed using GelCompar II (Applied Maths, SintMartens-Latem, Belgium). Gels were normalised by aligning the $700 \mathrm{bp}$ sizing standards included in each gel, and the area between 50 and $700 \mathrm{bp}$, which is normalised best by the GelCompar analysis software, was selected for numerical analysis. Following 
analysis, a UPGMA (Unweighted Pair Group Method with Arithmetic mean) dendrogram was constructed using the Dice similarity coefficient. An optimisation setting of $0.05 \%$ and a tolerance setting of $0.1 \%$ were applied to the analysis.

\section{Reproducibility}

Factors including DNA extraction method, DNA concentration, PCR efficiency and LICOR gel running conditions were kept standard for all strains used in this AFLP study, in order to maintain good reproducibility. Additionally, the type strain of $P$. ananatis was included in each template preparation and separated on each LI-COR gel as a positive control. Only gels where the band pattern of the type strain of $P$. ananatis was more than $75 \%$ similar to the original band pattern were analysed and included in the results.

\section{FAFLP analysis of Pantoea species}

In the UPGMA dendrogram (Fig. 1), produced from FAFLP analysis of the Pantoea strains, seven distinct clusters, one for each species of Pantoea, were identified. The clusters are defined by the grouping together of banding patterns that showed a linkage level of $50 \%$ to other clusters. This level of cluster delineation was comparable to those used in previous studies [16]. 
Fig. 1. UPGMA dendrogram based on FAFLP analysis of Pantoea species and plantpathogenic Enterobacteriaceae isolates using the selective primer combination Eco$\mathrm{C} / \mathrm{Mse}-\mathrm{GC}$. The levels of similarity representing the Dice similarity coefficient are expressed as percentages. The banding patterns adjacent to each branch are normalised and background-subtracted digitised gel strips processed in GelCompar. Pantoea type strains are in bold. $\mathrm{T}=$ type strain, $\mathrm{r}=$ Pantoea reference strain, $\mathrm{LMG}=\mathrm{Culture}$ Collection, Laboratorium voor Microbiologie, Ghent, Belgium, $\mathrm{BCC}=$ Bacterial Culture Collection, Forestry and Agricultural Biotechnology Institute, Pretoria, South Africa.

Twenty-four Pantoea strains used in this study were previously used in DNA hybridisation studies [4], [5], [9], [10], [11] and [12] and are regarded as reference strains (Fig. 1). Many of these strains were also investigated by protein profiling and 16S rRNA sequencing. Each of these strains fell within their intended species cluster in the AFLP dendrogram, thereby proving the usefulness of this technique for identification of Pantoea strains to the species level. Twenty-two of the non-reference strains used in this study clustered with their intended species, while two strains, BCC 103 (from sudangrass) and BCC 118 (from Eucalyptus infected with Colletogloeopsis zuluense), did not. Both strains were received as $P$. ananatis, but they clustered with $P$. stewartii subsp. indologenes. BCC 103 was isolated from sudangrass showing symptoms of leaf blotch disease, where the two causal agents were identified as $P$. ananatis and $P$. stewartii following physiological and biochemical tests [3]. BCC 103 fell into cluster VII with $P$. stewartii subsp. indologenes, indicating that this strain was initially misidentified as there is very little phenotypic difference between P. ananatis and P. stewartii subsp.

indologenes. BCC 118, isolated from Eucalyptus showing symptoms of Colletogloeopsis canker, was thought to be one of several $P$. ananatis strains, which can exist in a synergistic relationship with the fungus C. zuluense [19]. BCC 112 and BCC 114 were also isolated along with C. zuluense and both of these strains fell into cluster III with reference strains of $P$. ananatis. However, as BCC 118 clustered with strains of $P$. stewartii subsp. indologenes with a 50\% similarity, it is certain that this strain was originally misidentified as $P$. ananatis. This correlates with previous findings based on 16S rRNA sequencing by van Zyl [19], which indicated the possible association of two 
Pantoea species with the fungal pathogen, P. ananatis and P. stewartii. In both of the above cases, strains isolated from sudangrass and Eucalyptus infected with C. zuluense could only be identified to the species level as $P$. stewartii by phenotypic tests or $16 \mathrm{~S}$ rRNA sequencing. FAFLP analysis places both of these strains in the subspecies indologenes, demonstrating the ability of this technique to discriminate below the species level.

Since the original appearance of $P$. ananatis on Eucalyptus in 1998 [9], there have been numerous outbreaks of bacterial blight in South Africa. The FAFLP technique developed in this study is used as a routine diagnostic service by the FABI at the University of Pretoria to identify Pantoea strains causing the bacterial blight outbreaks. A continuously updated FAFLP database of Pantoea banding patterns now exists, to which possible Pantoea strains can be compared. This in-house database will assist us in the reliable identification of all Pantoea species, especially strains of the three most phytopathologically important species, P. stewartii subsp. stewartii, P. agglomerans and P. ananatis.

\section{References}

[1] C. Arnold, L. Metherell, G. Willshaw, A. Maggs and J. Stanley, Predictive fluorescent amplified-fragment length polymorphism analysis of Escherichia coli: high-resolution typing method with phylogenetic significance, J. Clin. Microbiol. 37 (1999), pp. 12741279.

[2] A.O. Avrova, L.J. Hyman, R.L. Toth and I.K. Toth, Application of amplified fragment length polymorphism fingerprinting for taxonomy and identification of the soft rot bacteria Erwinia carotovora and Erwinia chrysanthemi, Appl. Environ. Microbiol. 68 (2002), pp. 1499-1508.

[3] H.R. Azad, G.J. Holmes and D.A. Cooksey, A new leaf blotch disease of sudangrass caused by Pantoea ananas and Pantoea stewartii, Plant Dis. 84 (2000), pp. 973-979. [4] A. Beji, J. Mergaert, F. Gavini, D. Izard, K. Kersters, H. Leclerc and J. De Ley, Subjective synonymy of Erwinia herbicola, Erwinia milletiae, and Enterobacter 
agglomerans and redefinition of the taxon by genotypic and phenotypic data, Int. J. Syst. Bacteriol. 38 (1988), pp. 77-88.

[5] D.J. Brenner, G.R. Fanning, J.K.L. Knutson, A.G. Steigerwalt and M.I. Krichevsky, Attempts to classify Herbicola group - Enterobacter agglomerans strains by deoxyribonucleic acid hybridization and phenotypic tests, Int. J. Syst. Bacteriol. 34 (1984), pp. 45-55.

[6] D.A. Cooksey, Galls of Gypsophila paniculata caused by Erwinia herbicola, Plant Dis. 70 (1986), pp. 464-468.

[7] D.L. Coplin, D.R. Majerczak, Y. Zhang, W. Kim, S. Jock and K. Geider, Identification of Pantoea stewartii subsp. stewartii by PCR and strain differentiation by PFGE, Plant Dis. 86 (2002), pp. 304-311.

[8] E.J. Cother, R. Reinke, C. McKenzie, V.M. Lanoiselet and D.H. Noble, An unusual stem necrosis of rice caused by Pantoea ananas and the first record of this pathogen on rice in Australia, Aust. Plant Pathol. 33 (2004), pp. 495-503.

[9] T.A. Coutinho, O. Preisig, J. Mergaert, M.C. Cnockaert, K.H. Riedel, J. Swings and M.J. Wingfield, Bacterial blight and dieback of Eucalyptus species, hybrids and clones in South Africa, Plant Dis. 86 (2002), pp. 20-25.

[10] F. Gavini, J. Mergaert, A. Beji, C. Mielcarek, D. Izard, K. Kerster and J. De Ley, Transfer of Enterobacter agglomerans (Beijerinck 1988) Ewing and Fife 1972 to Pantoea gen. nov. as Pantoea agglomerans comb. nov. and description of Pantoea dispersa sp. nov., Int. J. Syst. Bacteriol. 39 (1989), pp. 337-345.

[11] B. Kageyama, M. Nakae, S. Yagi and T. Sonoyama, Pantoea punctata sp. nov., Pantoea citrea sp. nov., and Pantoea terrea sp. nov. isolated from fruit and soil samples, Int. J. Syst. Bacteriol. 42 (1992), pp. 203-210.

[12] J. Mergaert, L. Verdonck and K. Kersters, Transfer of Erwinia ananas (synonym, Erwinia uredovora) and Erwinia stewartii to the genus Pantoea emend. as Pantoea ananas (Serrano 1928) comb. nov. and Pantoea stewartii (Smith 1898) comb. nov., respectively, and description of Pantoea stewartii subsp. indologenes subsp. nov., Int. J. Syst. Bacteriol. 43 (1993), pp. 162-173. 
[13] A.A. Myburg, D.L. Remington, D.M. O’Malley, R.R. Sederoff and R.W. Whetten, High-throughput AFLP analysis using infrared dye-labeled primers and an automated DNA sequencer, BioTechniques 30 (2001), pp. 348-357.

[14] L.D. Paccola-Meirelles, A.S. Ferreira, W.F. Meirelles, I.E. Marriel and C.E. Casela, Detection of a bacterium associated with a leaf spot disease of maize in Brazil, $J$. Phytopathol. 149 (2001), pp. 275-279.

[15] C. Pujol and C.I. Kado, Genetic and biochemical characterization of the pathway in Pantoea citrea leading to pink disease of pineapple, J. Bacteriol. 182 (2000), pp. 22302237.

[16] P.H.M. Savelkoul, H.J.M. Aarts, J. De Haas, L. Dijkshoorn, B. Duim, M. Otsen, J.L.W. Rademaker, L. Schouls and J.A. Lenstra, Amplified-fragment length polymorphism analysis: the state of an art, J. Clin. Microbiol. 37 (1999), pp. 3083-3091. [17] E. Stackebrandt and B.M. Goebel, Taxonomic note: a place for DNA-DNA reassociation and 16S rRNA sequence analysis in the present species definition in bacteriology, Int. J. Syst. Bacteriol. 44 (1994), pp. 846-849.

[18] F.C. Stewart, A bacterial disease of sweet corn, NY State Agric. Exp. Stn. Bull. 130 (1897), pp. 422-439.

[19] L.M. van Zyl, Factors associated with Coniothyrium canker of Eucalyptus in South Africa, Ph.D. Thesis, University of the Orange Free State, Bloemfontein, South Africa, 1999.

[20] L. Verdonck, J. Mergaert, C. Rijckaert, J. Swings, K. Kersters and J. De Ley, The genus Erwinia: a numerical analysis of phenotypic features, Int. J. Syst. Bacteriol. 37 (1987), pp. 4-18.

[21] P. Vos, R. Hogers, M. Bleeker, M. Reijans, T. van der Lee, M. Hornes, A. Frijters, J. Pot, J. Peleman, M. Kuiper and M. Zabeau, AFLP: a new technique for DNA fingerprinting, Nucleic Acids Res. 23 (1995), pp. 4407-4414.

[22] R.R. Walcott, R.D. Gitaitis, A.C. Castro, F.H. Sanders Jr. and J.C. Diaz-Perez, Natural infestation of onion seed by Pantoea ananatis, causal agent of center rot, Plant Dis. 86 (2002), pp. 106-111. 
[23] W.J. Wilson, M. Wiedmann, H.R. Dillard and C.A. Batt, Identification of Erwinia stewartii by a ligase chain reaction assay, Appl. Environ. Microbiol. 60 (1994), pp. 278284.

Appendix A. Supplemental material

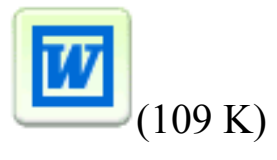

f.doc (2) Holp

Microsoft Word file 1.

Corresponding author. Tel.: +2712 420 4430; fax: +27124203266. 